Management Decision, Volume 48, Number 8, 2010, Pages 1304-1323

This article is (c) Emerald Group Publishing and permission has been granted for this version to appear here (https://dspace.lib.cranfield.ac.uk/index.jsp). Emerald does not grant permission for this article to be further copied/distributed or hosted elsewhere without the express permission from Emerald Group Publishing Limited.

www.emeraldinsight.com

\title{
Auditing Employee Ownership in a Neo-Liberal World
}

\begin{abstract}
:
Employee ownership has attracted much attention across the globe. Whether affected by the Global Financial Crisis (GFC), or not, this paper invokes a serious audit of empirical findings and cross-cultural approaches to an ideologically-sensitive agenda. Purpose: To canvass what is known about employee ownership in Neo-liberal political economies.
\end{abstract}

Design/methodology/approach: Literature review, cross cultural analysis and critique.

Findings: Indicate future research directions.

Research limitations/implications: Reconsideration of organizational configurations for possible greater application in the future.

Practical implications: Public policy imperatives.

Social implications: Re-regulation of neo-liberal markets

Originality/value: Knowledge/policy transfer.

Category: Literature Review

Key Words: Employee Ownership; Stock Ownership; ESOPs; Share structures; Management incentives/philosophies. 


\section{Introduction: Employee Share (stock) Ownership}

Employee ownership is currently attracting considerable attention in the press across the globe. For example, in February 2008, there were 1,436 press articles published, of which 683 focused on stock options, whilst 212 focused on workers' cooperatives (EFESO, 2008). There have also been a growing number of academic articles in the last few years, particularly in the U.S., where Employee Stock Ownership (ESO) or rather Employee Stock Ownership Plan (ESOP) diversification is an issue of concern. Such interest has been stimulated in part by the governments in North America, Europe, Australia and Asia promoting various forms of employee share ownership through a variety of schemes which, in turn, have resulted in considerable differences in the practice of employee participation between countries. Thus making generalizations about employee share ownership has to be done with considerable caution.

Furthermore, employee ownership terminology usage in the literature is not always clear and, at times, is confusing as articles refer to 'employee stock ownership;' 'employee's financial participation; 'profit sharing;' 'sharing ownership;' and ‘employee ownership'. Equally, what exactly constitutes an ESOP varies. A narrow definition is one where at least one employee receiving payment from an ESOP deems the firm as an employee stock ownership (ESO) employing company (Sengupta et al, 2007). A less restricted definition requires that a majority of non-managerial employees participate in the scheme for the company to be considered ESO employing (Robinson and Zhang, 2005). A broad-based definition theoretically covers the entire workforce. However, as most schemes never have 100 per cent coverage at any given time, since participation in the scheme calls for a minimum employment period, in practice, an ESO company is considered as such if a minimum of 50 per cent of the employees are covered by an ESO scheme (Pendleton, 2001). 
Yet, despite the variance of interpretation and practice, ESOPs are the longestestablished method for sharing ownership (Blasi et al, 2002). As such, employees acquire equity shares thus permitting them a shareholding in their employing company. For the majority of cases, employee share ownership plans consist of one of several components of the company's reward package. Additionally, employee ownership may come about through an employee buy-out or through the exiting owner wanting to pass on the business to the employees. In theory, employee ownership provides employees with additional rights, such as the right to share in the company's profits, access to information about the company's finances and operations and the right to participate in the management of the company (Rousseau and Shperling, 2003). These rights are intended to bring about fundamental changes in employee attitudes and behaviour, which may be reflected in a range of company-level outcomes such as improved productivity and financial performance (Rousseau and Shperling, 2003).

It was Sydney Webb (1912: 232) who noted that making an employee a shareholder in the business would 'stimulate his zeal and careful working and, as part owner of the capital, with which he works,' he will share responsibility in the business. Developed further as a concept in the 1950s by the lawyer and investment banker Louis Kelso, the ESOP was introduced in 1973 under the premise that the capitalist system would be stronger if all workers, and not just a few stockholders, could share in owning capital-producing assets and that tax benefits for ESOPs should be permitted and encouraged under employee benefit law (NCEO, 2008d). Thus, the assumption made is that sharing equity with most or all employees in a corporation is one way of gaining employees' involvement in profit-sharing programs (Blasi et al, 2002). 
However, the extent to which employees enjoy profit-sharing and information and participation rights varies considerably (Ben-ner and Jones, 1995; French, 1987) and that is considered to be a reason that the benefits from employee ownership vary substantially.

As emphasized, there exist various modes of employee ownership. At one end of the spectrum are workers' co-operatives, whilst the other end is populated by executive share-options. With the latter, participation in share ownership plans may be limited to just a few individuals, typically senior managers, or can be open to the entire workforce. Still, the assumption underling both profit-sharing and employeeownership is that the better re-distribution of the benefits of economic growth itself stimulates greater and continued economic growth (Lowitzsch, et al 2008). Broadly, three sets of schemes can be distinguished.

Direct: Through using one or more share plans, employees become registered as the shareholders of a majority of the shares in their company. In order to do so, employees may acquire shares over time, perhaps as bonuses or as part of their remuneration. Some share schemes offer tax advantages to the company and employees. Alternatively, the shares in the company could initially be bought by an employee trust which later are distributed, in part or whole to individual employees. As a result shares may be held individually or collectively. In the UK, there are three main types of non-cash, profit sharing schemes: Approved profit sharing; Save as You Earn (SAYE) schemes, also referred to as savings-related share- option schemes or 'share-save' schemes (initially established under the terms of The Finance Act 1980); 
and Company share options schemes. For these schemes to be put into operation, clear agreement needs to be reached between employer and employees. Employees must receive their shares in addition to their wages or salaries; the share price must be fixed beforehand and the employees' shares must be related to profits (Morris et al, 2006). Whilst cash schemes are the simplest method of distributing profits to employees, share options schemes, on the other hand, provide links between individual rewards and organizational success in profit terms more on a long-term basis (Morris et al, 2006).

Indirect: In this case, shares are held collectively on behalf of employees, normally through an employee trust. An indirect model of employee-ownership is through a cooperative structure (such as the Industrial and Provident Society structure) which provides benefits to the members. The trust might hold the shares in perpetuity or distribute them to individual employees, or a combination of the two. The trust also can buy shares back from employees particularly those who want to sell on their retirement. For example, a legal arrangement can be reached whereby an asset is deposited into an escrow account under the trust of a neutral third party (escrow agent) pending satisfaction of contractual contingencies or conditions, and who, in turn, will deliver the asset to the party as prescribed by the contract. Placing shares into an employee trust can have tax advantages and also provides an effective way of raising bank finance to acquire the shares (financing an employee buyout).

With both the direct and indirect models, there exist a plethora of variations. On the one hand, employees acquire only a small minority stake. On the other, a large proportion of company share possibly even the entire share capital, is owned by the 
employees. As far as employee-owned enterprises (EOE) are concerned, they often adopt profit sharing schemes, where the profits of the enterprise are shared with the employees. To safeguard such arrangements, boards of directors are constituted, elected directly by the employees.

The Co-operative: A corporation owned entirely by its employees (co-operative, coownership, partnership) will not have its shares traded publicly on stock markets. Cooperatives, or co-ops, emerged in response to economic and social inadequacies and represent a legal entity owned and democratically controlled by its members. The International Co-operative Alliance's Statement on the Co-operative Identity defines a co-operative as 'an autonomous association of persons united voluntarily to meet their common economic, social and cultural needs, and aspirations, through a jointlyowned and democratically-controlled enterprise' (Zeuli and Cropp, 2004). Cooperatives are businesses owned and controlled by the people who use its services or who work in the business.

The Fenwick Weavers Society has been posited as being the first co-operative. It was founded in 1761 to promote and maintain high standards in the craft of weaving, but soon became involved in the bulk purchase of oatmeal for re-sale to its members (Monklands, 2008). Shortly after, Rochdale's mill workers set up the Rochdale Equitable Pioneers Society whose underlying purpose was that of member self-help. Their co-operative existed for the benefit of its members and the improvement of their social and household condition (Monklands, 2008). They also worked out their aims and purposes, and committed them to paper in 1844 in the form of nine specific rules, the Rochdale Principles of Co-operation. The nine rules were: open membership; 
democratic control; distributing profits to members in proportion to their spending; paying small amounts of interest on capital; political and religious neutrality; cash trading; no credit; promotion of education; and quality goods and services, including distributing a share of profits according to purchases (Monklands, 2008).

Recognising the considerable variance of employee ownership schemes, this paper examines the nature of different forms of employee ownership and whether an additional level of difference exists according to regional or country idiosyncrasies. A sharp distinction is made between employee ownership and the mainstream, minority employee share plans in large enterprises. This paper also highlights the fact that future research needs to distinguish between the various forms of employee share ownership if the impact of share ownership is to be more precisely understood and calibrated.

\section{A 'global' Audit of ESOPs}

The United States: In the U.S., an ESOP is a retirement plan in which the company contributes its stock for the benefit of the company's employees (SEC, 2008). U.S. based ESOP employees never buy or hold stock directly (SEC, 2008). As such, an ESOP is different from other non-retirement plans such as employee stock options plans which give the employee the right to buy their company's stock at a set price within a certain period of time (SEC, 2008). Employee ownership in the U.S. takes four broad forms and a number of combinations (NCEO, 2008c).

- ESOPs, stock bonus plans and profit sharing plans primarily invested in employer stock; 
- 401(k) plans primarily invested in employer stock;

- broad-based stock option plans; and

- stock-purchase plans.

ESOPs are the most popular employee-ownership scheme in the U.S according to the NCEO (2008c). Approximately 70 per cent of ESOP owners are employed in large, public companies (Rousseau and Shperling, 2004). In 2007, there were 9,774 ESOPs, spread across 11.2 millions employee owners in over 11,000 companies, holding 630 billion Euros in assets (Rosen, 2008; NCEO, 2008a). The NCEO (2008b) definition of ESOPs is broad and includes plans filed as ESOPs, stock-bonus plans and profitsharing plans primarily invested in company stock (Rosen, 2008). Whilst profitsharing and stock-bonus plans are not technically ESOPs, they are included because there are functionally few differences, especially for the participants (Rosen, 2008). Other employee-ownership schemes, additional to ESOPs, have some 25 million employee owners, holding more than 1,000 billion Euros in assets (NCEO, 2008a). Overall, in the U.S., the broad-based stock options (grants given to at least half of a firm's workforce) have been increasing steadily, from 17 per cent in 1993 to 39 per cent in 1999 (Rousseau and Shperling, 2004).

The United Kingdom: In the UK, employee-ownership associations (EOAs) comprise of employee-owned and trust-owned businesses. These EOAs came about predominately in two ways. One stream of EOAs is composed of management and employees who benefitted from the buy-outs of public-sector firms undergoing privatization (most in the late 1980s and early 1990s). These were predominately highly-unionized firms, pursuing highly-leveraged buy-outs with loans from central or 
local government bodies (Pendleton, 2001). The second stream of EOAs arose from employee-ownership conversion from the private sector where owners wanted to divest themselves of, or exit from the business. Many of these were owner-managed firms. Typical motivation for conversion were, and are the protection of the firm from take-over and paternalistic sentiment concerning the welfare of employees (Pendleton, 2001). According to the EOA (2008), employee ownership is about the majority in the company owning part of it, whether via a trust or shares, and where no outside interest has a controlling stake.

Europe: Shared ownership plans in Europe are considerably diverse due to historical and institutional arrangements paralleled by a huge diversity in tax treatment. Across Continental Europe, studies of employee ownership report mixed results in terms of employee motivation and employee and company performance ( $\mathrm{D}^{\prime}$ Art and Turner, 2004; EFESO' 2005; Pourceau, 2003; Poutsma and de Nijs, 2003). Employee financial participation in Europe has been more influenced by profit sharing, with government and trade unions in support of such an arrangement (D' Art and Turner, 2004; Poutsma and de Nijs, 2003). In contrast to the UK, where there has been a trend to introduce ESOPs in unionized enterprises (Gregg and Machin, 1988; Pendleton, 1997), in the European Union (EU), union representation and employee share ownership co-exist and the two appear to function largely independently of each other (Pendleton, 2005). Union involvement in the design, implementation and operation of employee share plans in most cases is minimal. Additionally, the trend for privatization of state-owned companies has contributed to wider employee ownership. In Ireland, for example, nearly half a million employees were recorded as being covered by 'profit-sharing' schemes between 1983 and 2003 (D' Art and Turner, 2005). 
In contrast, in the early 1980 s, both Scandinavia and the EU generally appeared to favour schemes of collective, capital formation in preference to schemes of financial participation based at the level of the individual firm (European Trade Union Institute, 1983; LO, 1980; Meidner, 1978). However, since 1987, with the development of social partnership between EU governments and employers, this position has largely been abandoned in favour of firm-level profit sharing or employee share-holding schemes (D' Art and Turner, 2000; 2005). EU leaders seem uncertain as to their role in employee-owned enterprises (Long, 1978). Although unions have a role in conceptualizing and/or initiating the "ideal type" of employee ownership, (Freund, 1972), once ideas become a reality the union's role tends to be superseded. The reason is conflict of interests between labour and capital and the need for the unions to maintain their traditional role (Long, 1978). In numerous instances where unionized companies have converted to employee ownership, companies have remained unionized (Long, 1978).

In Germany, 73 per cent of companies call for greater employee share ownership whilst in Spain, legislation in support of employee-owned companies (sociedades laborales) is being prepared (EFESO, 2008). France, on the other hand, exhibits contradictions as the government plans to develop employee financial participation more in SMEs. The President has so far displayed an interest in unblocking employee savings to boost private consumption and investment in the more medium sized French business organization. In contrast, 'The Movement of French Enterprises' (MEDEF) organized a 'Tour de France' to more broadly promote employee share ownership (EFESO, 2008). For example, France Telecom, Société Générale, Essilor and Saint-Gobain have all adopted ESOPs (EFESO, 2008). Overall and similar to 
Germany, French law makes provision for employees of large, publicly-listed companies to elect two types of directors to represent employees. Partially privatized companies must reserve two or three seats, depending on board size, for directors elected by employees by right of employment. Additionally, employee-shareholders in any public company have the right to elect one director whenever they hold at least 3 per cent of outstanding shares. Ginglinger et al (2010) found that employee representation on corporate boards in France seems to be at least value-neutral, with some evidence supporting an actual increase in firm valuation and profitability when employee-shareholders elect company directors. However, when the firm's employees are represented by radical, left-wing unions, the financial payout is significantly reduced, whilst ironically corporate valuation is unaffected and firm profitability is significantly increased due to a more structured corporate governance regime and demanding climate of industrial relations (Ginglinger et al 2010). In Italy employee-share ownership still seems to be absent from political debates. In comparison to many other European countries, Italy seems to be becoming marginalized in this area (EFESO, 2008).

Overall, some 2,500 of the largest European companies now have 8.2 million employee owners across Europe, holding 260 billion Euros in value (EFESO, 2008).

Japan: Japanese employee share ownership plans (4.4 per cent of all firms in Japan in 1960 to 95.9 per cent in 1992) differ from their U.S. and UK counterparts (Kato and Morishima, 2002). For a start, there are no tax incentives to employee share participation for Japanese corporations. However, employees are encouraged to 
participate in share ownership plans by the company matching the employee's contribution and bearing the administrative cost. Executives are often ineligible for membership. Shares are held in a trust, though each participant has the right to withdraw their shares which then become privately owned and cannot be re-entered into the fund.

Retired workers are required to exit completely. Further all employees leaving the plan must sell their shares to the trust at current market value. The trust is required to appoint a general director, who is a participant in the plan (but not an executive of the firm) and who is chosen democratically by participants in the plan on a oneparticipant, one-vote, basis. These trusts act as a collective voice for the employee owners, ensuring that their views are incorporated at all levels of company management. These trusts, or employee shareholder associations, have the capacity to represent employees' opinions as a whole and, thus have become a powerful voice.

\section{Spread of Practice}

As can be seen substantial differences exist between countries in the structure and nature of owner/representative participation. The three leaders in the EU, with employee coverage averaging over 50 per cent, are the UK, France and Poland (Lowitzsch et al, 2008). Certain countries have decentralized systems of indirect participation whilst others have centralized arrangements, and still others have a combination of the two. In the UK, it appears that share ownership tends to be found in unionized establishments through mainly single-channelled representation where all or the most representation occurs through the union and comparable bargaining 
channels (Gregg and Machin, 1988; Pendleton, 1997). Other countries, such as Germany, have dual systems, one through union representation in terms of collective bargaining and a further separate representation through works councils. In many instances, union representation and employee share ownership co-exist and function largely independently of each other, with little union involvement in the design, implementation and operation of employee share plans (Pendleton, 2005; 2006). The exception to this is majority, employee-owned firms where unions are involved in mounting buy-outs (Pendleton, 2006).

\section{ESOPs Contextualized}

As has been argued, ESOPs are contingent on each country's laws and regulations and philosophic predisposition. The increased usage of ESOPs in neo-liberal economies has arisen primarily due to 'managerial incentivization' and favourable tax treatment in the hands of both the issuer and the recipients (Matsunaga, 1995). After the mid1970s, U.S. legislation which encouraged ESOPs saw the number of ESOP companies in the U.S. dramatically increase (Conte and Lawrence, 1992), reaching peaks in 1993 and 2005 - due to affordable tax and accounting practices. In the late 1980s, many public companies set up ESOPs but when, accounting rules changed in a way that was less favourable for ESOPs, many companies closed down their ESOPs and moved their contributions of stock to 401(k) plans.

Despite the praises sung about share redistribution/participation, serious concerns have also been voiced (Odoi, 2007). The favourable accounting and tax treatment that facilitated the rise of ESOPs has often resulted in inflated corporate earnings, raising the legitimate concern that many firms adopted broad-based stock option schemes to provide an artificial boost to earnings rather than for sound business reasons 
(Kroumova and Sesil, 2005). The corporate frauds and scandals, beginning with Enron in 2001 highlighted incidents of extraordinary executive pay and stock option exercises, whilst employees suffered losses in their 401(k) plan. These scandals invoked new regulations and legislation, notably that of the Sarbanes-Oxley Act 2002. Moreover, starting from June 2005, U.S. firms have been subject to reporting stock options as an expense on their balance sheets (NCEO, 2005a). In March 2005, the IRS issued a correction to the accounting regulations of 2004, thus curbing further corporate abuse of employee incentive schemes, including ESOPs (SEC, 2008). In anticipation of such requirement, firms started granting options to fewer employees (NCEO, 2005b). Thus, since 2005, US firms are required to measure the 'fair value' of options and other equity awards at the time of the grant and then expense the value of the award. A similar trend in the UK has paralleled the US experience, whereby the Labour government, in 2003, scrapped tax relief on company contributions to employee benefit trusts with the intent of minimizing tax avoidance but as a result have made it more difficult for companies to be trust-owned (Odoi, 2007).

As can be seen, individual country laws influence whether or not employees are allocated control rights in the companies for which they work, whether they own shares in it or not. As highlighted in Germany, France and Japan, the law mandates that workers be represented on corporate boards. The German co-determination policy began in 1951 for mining, coal and steel companies, and was extended in 1976 to all firms with more than 2000 workers. The policy requires substantial worker representation, reserving between one-third and one-half of board seats on the supervisory board (Aufsichgrat) of publicly listed companies for that purpose (Fauver and Fuerst, 2006). A later law required that workers receive one-third of supervisory 
board seats in companies with between 500 and 2000 workers (Fauver and Fuerst, 2006).

Recognising the notable difference between countries holding a stakeholder philosophy such as Germany, against those with a shareholder philosophy such as the U.S.A, certain scholars still argue that employee participation in firm governance can be value-enhancing, particularly when companies are confronted with economic or financial distress (Acharya et al, 2008; Galai and Weiner, 2008). Allen et al (2007) and Claessens and Ueda (2008) support this view presenting empirical evidence that stakeholder-oriented firms often prosper when competing against purely shareholderoriented firms. In fact, Allen et al (2007) predict that firms in stakeholder-oriented societies, such as Germany and Japan where a close relationship exists between the enterprise and the banking system, will be more able to reduce the probability of firm bankruptcy despite the use of debt.

\section{Imperatives for Employee Ownership}

Different reasons drive a firm's decision to adopt an employee- ownership model. The objectives of profit sharing tend to vary according to the desire of particular initiator(s) (D' Art and Turner, 2004). Social harmonizers, recognising the altruistic proponents of these schemes, see them as a way to realize equity and social justice (D' Art and Turner, 2004). Couper (2006) has argued that the underlying values of selfhelp, equity, equality, democracy and solidarity are values required for finding a common voice and sense of responsibility. It is contended that there is a direct parallel with the employees' need to feel responsibility (self-help), belonging (community), involvement (democracy) and reward (equity) and the sustainable longterm direction for the business, drawing on genuine employee engagement (Couper, 
2006: 7). In the wholly employee-owned firms, 'the great strength of the partnership's model is that employees have a real stake in the business [...] co-ownership allows the partnership to take a long-term view, because we do not have to answer to external shareholders who are usually seeking quick returns' (Killen, quoted in Odoi, 2007: 1).

Managerial proponents have contended that employee ownership schemes enhance organizational outcomes such as productivity and profitability (D' Art and Turner, 2004). Long (1978: 755) stated that ESOP's will put each worker in the position of improving 'his own efforts towards costs minimization', thus enhancing the value of the enterprise and in turn, eliminating strikes, slowdowns, antiquated work rules and unreasonable wage-demands. Thus, the imperative proposed is that profit sharing and share ownership schemes represent an attempt to link pay with the performance of the firm as a whole, with the aim of engendering a commonality of interest. Even from an agency theory perspective, scholars have argued that agency costs can be reduced by aligning executive, managerial and employee compensation to firm performance (DeFusco et al., 1990; Jensen and Meckling, 1976). This is the case where particularly 'difficult to monitor' inputs from human capital will more likely adopt compensation plans that provide inexpensive substitutes for more formal monitoring, such as hiring more managers or supervisors (DeFusco et al, 1990; Jensen and Meckling, 1976). The hypothesis put forward by scholars is that employee monitoring is likely to be more severe in knowledge-based firms especially ones that are large and where intellectual capital is the main source of customer value, or in firms that are experiencing rapid growth (De Fusco et al, 1990). 
Similarly Rousseau and Shperling's (2004: 563) put forward the perspective that 'ownership is increasingly part of a larger set of practices for firms where a highlycommitted workforce is viewed as a competitive advantage'. In similar vein, Rosen et al $(2005 \mathrm{a} ; 2005 \mathrm{~b})$ state that when employees own a stake in the company, their attitude also sharpens as does the company's bottom line. Morris et al (2006: 328) found that in the UK the most common reason for employee ownership is 'to make employees feel that they are a part of the company and to create a feeling of involvement and interest in the company's fortune'. The SEC (2008) suggests that many companies use stock plans to compensate, retain and attract employees. Thus, broad-based ownership arrangements may reflect employer efforts to retain and motivate a collective of value-creating labour. For example, broad-based stock options are more common where monitoring costs are high, such as where intellectual capital drives value creation (Kroumova and Sesil, 2005).

However, and in contrast, firms may adopt broad-based options not to promote alignment, but rather because their expensing treatment makes them appear to be an inexpensive means of delivering compensation. This, in turn, suggests some companies adopt ESOPs for the wrong reason(s) and this may also mean that firms that could benefit from their use may be abandoning them unnecessarily.

Overall, the neo-liberal proponents of financial participation expect a diffusion of share ownership to establish people's capitalism (D' Art and Turner, 2004; Kelso and Hetter, 1967; Saunders and Harris, 1994)). Arguing from the unitary perspective, some have proposed that there is a convergence of the roles of owner, manager and worker, particularly in knowledge-intensive firms where expanded worker 
participation in ownership and related privileges include access to financial information and greater freedom in decision making (Rousseau and Shperling, 2004; Zardkoohi and Paetzold, 2004)

As share schemes have been principally used for social equity and employee motivation reasons, they have equally been used as anti trade union measures. Management of non-union firms, particularly in the US, use financial participation as part of a unitarist strategy to exclude trade unions. Profit sharing, or employee shareholding, is used as a defence or deterrent against union-organizing drives (Czarnecki, 1970; 2005; D' Art and Turner, 2004; McHugh et al, 1999). The reason for the adoption of employee ownership is the historical shift from the centrality of rigidly directing Taylorist 'hired hands' (Kouzmin, 1980) to the subtlety of influencing the thinking, values and self-managing norms and 'identities' of 'hired heads'. Bridging the paradigmatic Taylorist/Fordist 'thinking versus doing' breach remains an overarching legacy in Anglo-American managerial praxis, consolidated further in Neoliberalism (Kouzmin, 2009). The subtle re-branding of labour or employees into 'worker-owners' or 'employee-owners,' further advances the institutionalization of the 'worker-owner' identity within the neo-liberal ideology (Kouzmin, 1980).

\section{Employee Ownership Value}

Whatever the reasoning for adopting shareholding participation, a growing body of empirical evidence suggests that there is a weak, but positive relationship between the broad dispersion of ESOPs and superior firm performance outcomes such as employee productivity, firm profitability and stock performance (Klein, 1987). Blasi 
et al (2003:176), for example, have argued that a company cannot achieve desired motivation and participation effects without financial participation, as,

"telling employees to take ownership of their jobs rings hollow if management doesn't offer actual financial ownership or some share in the improved performance [...]. Without wealth sharing, in some form, it feels like the company is just trying to con you into working harder."

Based on the assumption that owners do not need to be motivated, one stream of the literature submits that ownership of itself creates the motivation for continuous performance improvement (Blasi et al, 2003). An agency-theory-informed stream of literature highlights the possible economic rewards as root causes of the beneficial motivational effect (BCI Group, 2002; Hallock and Salazar, 2003; Ittner et al, 2002; Sesil et al, 2002). Others argue that if an ESOP is combined with some of the basic rights of ownership, such as information about the company and participation in decision-making, that of itself will also have a positive impact on work attitude and behaviour (Gudmundson et al, 2003; Rosen and Carberry, 2002; Stack and Burlingham, 2002). Thus, there appears to be a performance premium associated with sharing stock options with the broader set of employees, especially in 'knowledge' intensive firms where better company performance is associated with the use of employee ownership (Pendleton, 2001; Sesil et al, 2003). Pendleton (2001) supports this case purporting that ESOP participation is more widespread within the financial sector due to employees higher knowledge of the characteristics of the plans and more generally in sectors with a higher concentration of non-manual employees who may be more familiar with the use and concept of stock savings. 
Some (Bonin et al, 1993; Craig and Penavel, 1992; Park et al, 2004) have argued that, while employee ownership is associated with higher productivity, the greater survival rate of these companies is not explained by greater employment stability, but rather by higher productivity, financial strength or compensation flexibility. Bonin et al (1993) have argued that the switch from focusing on profit maximizing to other optimizing criteria ensures workers-owners' interest in the firm's decision-making process and in their sharing of the surplus benefits. Thus, employee ownership companies may provide greater employment security in an effort to build a more co-operative culture, which can increase employee commitment, training and willingness to make adjustments when economic difficulties occur (Melgarejo et al, 2007; Park et al, 2004). It should be noted however, that the majority of the empirical studies examining ESOPs are carried out within the U.S. shareholder value market (Blasi et al, 2003), with only a few notable studies carried out in the European Union (EU) (Pendleton, 2001).

Overall, employee share plans or 'partnership capitalism' is found to increase the productivity level by about 4 per centage points, compared to firms that do not adopt such practice (Blasi et al, 2002). Total shareholder returns increase by about two per centage points relative to other firms, whilst profit levels go up by about 14 per cent (Blasi et al, 2002). Although certain studies have produced inconclusive results, overall research results have shown that employee ownership has a modest positive impact on workplace variables (Blasi et al., 1996; Huselid, 1995; Klein, 1987; Pendleton et al, 1998; Pfeffer, 1995; ). Certainly one consistent theme has been the emphasis on good human resource practice and the impact of that on firm 
performance and competitive advantage (Huselid, 1995; Morris et al, 2006; Pfeffer, 1995).

\section{What we Know (or do not Know) about ESOPs}

As shown attention has focused on exploring the relationship between profit sharing and organizational performance, controlling for possible exogenous and endogenous effects including firm size, market location, product portfoliom, date of establishment and individual country effects (D' Art and Turner, 2004). Firm performance has been measured and compared through such components as pre-adoption and post-adoption of ESOPs, as well as between ESOP and non-ESOP firms. In addition to financial performance, profit sharing impact on the level of productivity, service quality, product to market time and rate of innovation, have also been examined (D' Art and Turner, 2004). Various types of employee ownership in Britain, Ireland, Japan, Scandinavia, Spain and the former Eastern bloc have also been studied (D' Art and Turner, 2004; Jones and Kato, 1995; Melgarejo et al, 2007; Morris et al, 2006; Pendleton et al, 1998; Pendleton, 2001; Poole, 1988). Further, the presence or the absence of staff associations (unions) and the impact of that on share ownership adoption have also equally been given attention (Morris et al, 2006; Poole, 1989).

Some scholars (Gudmundson et al, 2003; Rosen and Carberry, 2002; Stack and Burlingham, 2002) have found a link between employee share ownership, financial participation and involvement in decision making, resulting a 'culture of ownership', on the one hand, and innovation on the other, due to 'initiation and implementation of innovation being significantly enhanced when employees are empowered to take action' (Gudmundson et al, 2003: 14). Certain scholars contend that firms with 
employee share ownership are able to tap into human capital by operating 'policies that draw more fully on worker skills and innovation' (Kruse et al, 2003: 6).

Research has also shown that companies with employee share ownership (50 per cent or more), or with significant levels of employee financial participation, have higher productivity and financial performance, greater innovation, higher levels of customer loyalty, lower staff turnover, increased shareholder returns, productivity and financial performance (Conyon and Freeman, 2001; Freeman et al, 2004; Kato and Morishima, 2002; Lamberg et al, 1993; Michie et al, 2002).

An overall literature review (Conte and Svejnar, 1990; Doucouliagos, 1995; Kruse and Blasi, 1997; Kruse et al, 2007; Pérotin and Robinson, 2003), suggests that employee share ownership has limited but positive effects on organizational performance and particular productivity, albeit these outcomes are often small and/or statistically insignificant. Studies based on western-market economies suggest that employee share-ownership and profit-sharing have had positive effects on workers incentives and productivity (Blinder, 1990). In similar vein, studies from new EU entrants, such as the Baltic countries, Poland, Hungary and Slovenia, indicate that post-privatization performance of employee-owned firms have been similar to that of other types of firms (Uvalić and Vaughan-Whitehead, 1997). The Doucouliagos (1995) study suggests that the positive effects tend to be more prominent and statistically significant amongst firms with majority employee ownership rather than amongst firms with employee share plans, (Conte and Svejnar, 1990). Although most share-ownership plans do not appear to fundamentally transform the employment relationship, evidence has emerged which highlights the minimizing of the 'free-rider' 
syndrome and the redirection of alignment concerns common to large and listed enterprises (Sengupta, 2008).

One theme runs through many of the studies and that is the lack of transformation of the firm through employee relationship and that may be due to the fact that in the majority of cases 'shareholders do not own the corporation, which is an autonomous legal person' (Heracleous and Lan, 2010: 24). Thus, when company 'directors go against shareholder wishes, even when a loss in value is documented, courts tend to side with directors the vast majority of the time' and, as such, render shareholders impotent (Heracleous and Lan, 2010: 24). Although share-ownership schemes transfer equity to employees, in many cases this is proportionally small and so little expectation is created on the part of those employees involved in transforming the way the company is run. However, in companies with a substantial employee ownership (50 per cent or more), employee expectations have been captured as different (Pendleton et al, 1998). Some have argued that the effects of employee ownership are greater or are achieved only when there is employee participation in decision-making (Pendleton et al. 1998; Addison and Belfield, 2001). In employeeowned firms, employee participation appears requisite for achieving a full sense of ownership; namely the right to determine how an asset is used and disposed off (Pendleton et al. 1998; Addison and Belfield, 2001; Rosen et al, 2005; Kaarsemaker and Poutsma, 2006).

Yet, despite findings for and against, the majority of studies of ESOPs favourably conclude that the advantages of employee involvement and/or ownership of the enterprise outweigh the disadvantages. However, the voice of concern (Kaarsemaker 
and Poutsma, 2006) relates to the simplicity of the studies and inadequacy of research methodology. Kaarsemaker, and Poutsma (2006) especially highlight to,

- an inadequate probing of the conditions supporting positive employee ownership outcomes. Are identified positive effects due to ownership structure or other factors such as leadership?

- an inadequate study of the experiences/concerns of the individual in terms of happiness, stress, adequacy of earnings or sufficiency of pensions;

- an inadequate scrutiny of the relationship between improved productivity and individual well being, despite the volume of conclusions linking positive outcomes for the company and the employee; and

- an undue focus on EO enterprises in Anglo-Saxon nations rather than broader international comparisons especially where financial participation is supported by task incentives such as in Austrian, Germany, Ireland, France, etc.

Certainly studies of multi-national corporations (MNC's), strongly suggests that the positive outcomes attributed to ESOPs enterprises could be more the result of (Kakabadse and Kakabadse, 2008),

- capable leadership;

- well-trained and developed management, both strategically and operationally capable despite pressures for meeting short-term targets;

- well-thought through human resource management (HRM) policies promoting talent management, collaborative/team ways of working, work/life balance, coaching and counselling;

- responsible and disciplined governance; and 
- a positive orientation to corporate social responsibility (CSR) and sustainability adoption.

\section{Where to for ESOPS?}

The assumptions underlying employee ownership research point to the fact that employee ownership modifies the relationship between workers and their work organization which, in turn, has implications for the quality of working life of employees, for their performance and the performance of the organisation (Tannenbaum, 1983). Some argue that such effects occur through companies designed to be more egalitarian, participative and supportive, appealing to a sense of identification with, and contributing to, the success of the enterprise (Tannenbaum, 1983). However, other studies have shown modest outcomes of worker participation as they had relatively little influence compared with that of the enterprise managers (Obardovic, 1970). Workers who were members of the councils were only slightly more satisfied with their jobs than workers who were not council members (Obradovic, 1970).

On a broader scale, one powerful call is for employee ownership studies to be pursued on a cross-cultural basis. A number of researchers (Blasi, 1988; Hallock and Salazar, 2003; Klein and Hall, 1988) propose that future research should avoid the manipulation of large, readily-available data sets which have dominated previous studies and should concentrate more on detailed studies of individual firms that have adopted ESOPs. Some critics (Odoi, 2007) argue that although there is a range of employee-ownership business models, there is an overall unawareness, not only amongst employees but also amongst accountants and lawyers, about how these 
models work and how co-owned schemes have been or are structured (Kouzmin, 1993).

The alternative voice is that the study of employee-ownership models is hampered not so much by empirical concerns as much as by paradigmatic and ideological constraints, especially in relation to the on-going presence of managerial prerogatives and increasing disparities in remuneration in Neo-liberal economies (Kakabadse, et al 2004). Then there is the question of $20^{\text {th }}$ Century European history. Commissar, entrepreneur, manager and bureaucrat constitute one social cleavage. They cohere and articulate similar interests by virtue of the common problems and experiences to which their position exposes them: the logic of authority relations within formal organizations (Kouzmin, 1980). One has yet to see a 'distributive,' rather than a 'production,' socialism (Kouzmin and Korac-Kakabadse, 1997), the latter having led to a universal embrace of a highly-exploitative, technical division of labour.

Within the grip of 'means' over 'ends', Eastern Europe did struggle to find some expression of labour concerns within 'Fordist' industrialism. Despite the challenges, how can one seriously engage with the question of employee ownership whilst ignoring such rich veins of experience from Eastern Europe? Even the Chinese have entered into the fray (li et al, 2005).

The case for cross-cultural, bottom up research is simply overwhelming. Moreover, there is a need for better understanding how employee-ownership firms perform in relation to the non-employee ownership firms in a globally-depressed market, and, more importantly, whether employee-ownership schemes will continue to survive in a 
constantly changing labor market? Moreover, the literature is predominately silent on whether:

- shareholding structure, of itself, determines higher-quality performance at the company, team and individual level or not;

- quality management, supportive organization culture and a positive orientation towards CSR and sustainability result as much from capable leadership and forward thinking HRM policies and practices, rather than just financial and legal structures,

- security of employment, particularly under global financial crisis conditions, may or may not have the beneficial effects discussed above,

- the tension between employees and management, and between parts of the organization is a phenomenon of most medium to large-sized organizations, irrespective of ownership structure. The leadership capability of top management to minimize misalignment effects on company performance emerges as a critical factor, possibly less so than ownership structures.

Certainly future study of the effects and benefits of employee participation/employee ownership schemes can no longer remain within the paradigm of, is it good to have or not? The need is to examine ESOP schemes as one alternative available to the firm in their quest for performance improvement within a context of rapidly changing economic conditions. 


\section{References}

Acharya, V. V., Myers, S. and Rajan, R. (2008), 'The internal governance of firms," CEPR Discussion Papers 7210, Centre for Economic Policy Research, London.

Addison, J. and Belfield, C. (2001), "Updating the determinants of firm performance: Estimation using the 1998 UK Workplace Employee Relations Survey", British Journal of Industrial Relations, Vol. 39, No. 3, pp. 341-66.

Allen, F., Carletti, E. and Marquez, R. (2007), "Stakeholder capitalism, corporate governance and firm value", EFA 2007 Ljubljana Meetings Paper, ECGI Finance Working Paper No. 190/2007, Wharton Financial Institutions Center Working Paper, No. 09-28.

BCI Group. (2002), "North American employee ownership survey results", Pension Benefits, Vol. 9, Issue 8, p. 6.

Ben-ner, A. and Jones, D.C. (1995), 'Employee participation, ownership and productivity: A theoretical framework', Industrial Relations, Vol. 34, No. 4, pp. $532-554$.

Blasi, J. (1988), Employee ownership: Revolution or rip off? Ballingen Publishing Company, Cambridge.

Blasi, J., Conte, M. and Kruse, D. (1996),"Employee stock ownership and corporate performance among public companies", Industrial and Labour Relations Review, Vol. 50, No.1, pp. 60-79.

Blasi, J., Kruse, D. and Bernstein, A. (2002), In the company of owners: The truth about stock options and why every employee should Have them, Basic Books, New York.

Blasi, J., Kruse, D. and Bernstein, A. (2003), In the company of owners: the truth about stock options (and why every employee should have them), Basic Books, New York.

Blinder, A.S. (ed.) (1990), Paying for productivity - A look at the evidence, Washington, DC, The Brookings Institute.

Bonin, J. P., Jones, D. C. and Putterman, L. (1993), "Theoretical and empirical studies of producer co-operatives: Will the twain meet?" Journal of Economic Literature, Vol. 31, pp. 1290-320.

Claessens, S. and Ueda, K. (2008), "Banks and labour as stakeholders: Impact on economic performance", IMF Working paper, International Monetary Fund Washington, DC.

Conte, M. A. and Lawrence, H. (1992), "Trends in ESOPs", in Turner, J. and Beller, D. L. (Eds.), Trends in pensions, Government Printing Office, Washington, DC, pp.135-48.

Conte, M. A. and Svenjar (1990), "The performance effects of employee ownership plans" in Blinder, A. (ed.), Paying for productivity: A look at the evidence, Washington DC: Brookings Institution, pp. 143-181 
Conyon, M.J. and Freeman, R.B. (2001), Shared modes of compensation and firm performance: UK evidence. Working Paper 8448, National Bureau of Economic Research, Cambridge, MA, August. www.nber.org/papers/w8448.pd

Core, J. E. and Guay, W.R. (2001), "Stock options for non-executive employees," Journal of Financial Economics, Vol. 61, No.2, pp. 253-287.

Couper, F. (2006), 'Mutuality: Invaluable lessons from a classic model', Strategic Direction, Vol. 22, No. 2, pp. 6-8.

Craig, B. and Pencavel, J. (1992), "The behaviour of worker cooperatives: the plywood companies of the Pacific Northwest", American Economic Review, Vol. 82, pp. 1083-1105.

Czarnecki, E. R. (1970), "Effects of profit sharing plans on union organising efforts," Personnel Journal, pp. 763-73.

D' Art, D. and Turner, T. (2000), "Social partnership in Ireland: a view from below," The Journal of the Irish Academy of Management, Vol. 21, No.1, pp. 51-69.

D' Art, D. and Turner, T. (2004), "Profit sharing, firm performance and union influence in selected European countries," Personnel Review, Vol. 33, No.3, pp. $335-50$.

D' Art, D. and Turner, T. (2005), "The revival of profit sharing: cyclical recurrence or paradigmatic shift?" Kemmy Business School, University of Limerick, Working Paper, Department of Personnel and Employment Relations, Limerick.

DeFusco, R. A., Johnson, R. R. and Zorn, T. S. (1990), "The effect of executive stock option plans on stockholders and bondholders", The Journal of Finance, Vol. 45, No.2, pp. 617-627.

Doucouliagos, C. (1995) 'Worker participation and productivity in labor-managed and participatory capitalist firms: a meta-analysis', Industrial and Labor Relations Review, 49, pp.58-77.

EFESO (2005), "Home page", European Federation of Employee Share Ownership, Brussels, available at: www.efesonline.org, (Accessed: 05.03.2008).

EFESO (European Federation of Employee Share Ownership), (2008), EFES Newsletter, March 8, Brussels. http://www.efesonline.org/efes20news/2008/efes20newsletter20203200820en.htm (Accessed: 05.03.2008).

EOA (Employee Ownership Association) (2008), 'Member companies', $\mathrm{http}: / / \mathrm{www} . e m p l o y e e o w n e r s h i p . c o . u k / m e m b e r-c o m p a n i e s . h t m \quad$ (Accessed: 05.03.2008).

European Trade Union Institute (1983), Trade Unions and Collective Capital Formation: A Review of initiatives in Western European Countries. Brussels.

Fauver, L. and Fuerst, M. E. (2006), "Does good governance include employee representation? Evidence from German corporate boards", Journal of Financial Economics, Vol. 82, pp. 673-710.

Freeman, R.B., Kruse, D. and Blasi, J. (2004), 'Monitoring colleagues at work: Profit sharing, employee ownership, broad-based stock options and workplace performance in the United States', A paper presented at the Association for 
Comparative Economic Studies Conference, Manchester Grand Hyatt, San Diego, 3-5 January.

French, J. (1987), "Employee perspectives on stock ownership: Financial investment or mechanism of control", Academy of Management Review, Vol. 12, No. 3, pp.427435 .

Freund, J. (1972), The sociology of Max Weber, Penguin, London.

Galai, D. and Wiener, Z. (2008), "Stakeholders and the composition of the voting rights of the board of directors", Journal of Corporate Finance, Vol. 14, pp. $107-117$.

Ginglinger, E, Megginson, W. L. and Waxin, T. (2010), "Employee ownership, board representation, and corporate financial policies", Social Science Research January, papers.ssrn.com/sol3/papers.cfm?abstract_id=1252645 (accessed: 15.04.2010).

Gregg, P. and Machin, S. (1988) 'Unions and the incidence of performance-linked pay schemes in Britain', International Journal of Industrial Organisation, (6), pp.91-107.

Gudmundson, D., Tower, C.B. and Hartman, E.A. (2003), "Innovation in small businesses: Culture and ownership structures do matter", Journal of Developmental Entrepreneurship, Vol. 8, No. 1, pp.1-17.

Hallock, S. and Salazar, R. J. (2003), "A research model to investigate the organizational impact of an ESOP," International Journal of Sociology and Social Policy, Vol. 23, No. 12, pp. 47-63.

Heracleous, L. and Lan, L.L. (2010) ‘The Myth of Shareholder Capitalism' Harvard Business Review, April, 24-24.

Huselid, M. A. (1995), "The impact of human resource management practices on turnover, productivity, and corporate financial performance," Academy of Management Journal, Vol. 38, pp. 635-672.

Ittner, C., Lambert, R. and Larcker, D. (2002), "The structure and performance consequences of equity grants to employees of new economy firms," Journal of Accounting \& Economics, Vol. 34, Nos. 1-3, pp. 89-127.

Jensen, M. and Meckling, W. (1976), "Theory of the firm: managerial behaviour, agency costs and ownership structure", Journal of Financial Economics, Vol. 3, pp. $305-360$.

Jones, D. C. and Kato, T. (1995), "The productivity effects of employee stockownership plans and bonuses: Evidence from Japanese panel data", The American Economic Review, Vol. 85, No.3, pp. 391-414.

Kaarsemaker, E., and Poutsma, E. (2006), "The fit of employee ownership with other human resource management practices: Theoretical and empirical suggestions regarding the existence of an ownership high-performance work system, or “Theory O", Economic and Industrial Democracy, Vol. 27, No. 2, pp. 669-685.

Kakabadse, A. and Kakabdse, N. (2008), Leading the Board, Plagrave, London.

Kakabadse, N., Kakabadse, A. and Kouzmin, A. (2004), "Directors' remuneration: The need for a geo-political perspective", Personnel Review, Vol. 33, No. 5, pp. $561-582$. 
Kato, T. and Morishima, M. (2002), "The productivity effects of participatory employment practices: Evidence from new Japanese panel data". Industrial Relations, Vol. 41, No. 4, pp. 487-520.

Kelso, L. and Hetter, P. (1967), How to turn eighty million workers into capitalists on borrowed money, Random House, New York.

Klein, K. J. (1987), "Employee stock ownership and employee attitudes: A test of three models", Journal of Applied Psychology, Vol. 72, No. 2, pp. 319-32.

Klein, K. J. and Hall, R.J. (1988), "Correlates of employee satisfaction with stock ownership: Who likes an ESOP most?" Journal of Applied Psychology, Vol. 73, No.4, pp. 630-8.

Kouzmin, A. (1980), "Control in Organizational Analysis: The Lost Politics", in Dunkerley, D. and Salaman, G. (Eds.), 1979 International Yearbook of Organizational Studies, Routledge and Kegan Paul, London, pp. 56-89.

Kouzmin, A. (1993), "Review Essay" - Labour Relations in Eastern Europe: Organizational Design and Dynamics [(Petkov, K. and Thirkell, J.E.M.), Routledge, London, 1991], Organizational Studies, Vol. 14, No. 1, pp. 127-132.

Kouzmin, A. (2009),"Market Fundamentalism, Delusions and Epistemic Failure in Policy and Administration", Asia-Pacific Journal of Business Administration, Vol.1, Issue 1, March/April, pp. 23-39.

Kouzmin, A. and Korac-Kakabadse, N. (1997), "From phobias and ideological prescription: Towards multiple models in transformation management for socialist economies in transition," Administration \& Society, Vol. 29, No. 2, May, pp. 139-188.

Kroumova, M. and Sesil, J.C. (2005), "Intellectual capital, monitoring and risk: what predicts the adoption of broad-based employee stock options?" SSRN Working Paper Series.

Kruse, D. and Blasi, J. (1997) 'Employee ownership, employee attitudes, and firm performance: a review of the evidence,' in Lewin, D., Mitchell, D. and Zaira, M (eds.), The Human Resource Management Handbook, London: JAI Press.

Kruse, D., Blasi, J. and Park, R. (2007) 'Shared Capitalism in the U.S. Economy: Prevalence, Characteristics, and Employee Views of Financial Participation in Enterprises', Paper presented for the Russell Sage/NBER conference in New York City, October 2006.

Kruse, D., Freeman, R.B., Blasi, J., Buchele, R., Scharf, A., Rodgers, L. and Mackin, C. (2003),"Motivating employee owners in ESOP firms: Human resource policies and company performance", NBER Working Paper No. 10177, National Bureau of Economic Research, Cambridge, http://www.nber.org/papers/w10177.pdf (accessed: 20.02.2009).

Lamberg, J.A., Savage, G.T. and Pajunen, K. (2003), "Strategic stakeholder perspective to ESOP negotiations: The case of United Airlines", Management Decision, Vol. 41, No.4, pp. 383-393.

Li, J., Lam, K. and Moy, J.W. (2005), "Ownership reform amongst state firms in China and its implications", Management Decision, Vol. 43, No. 4, pp. 568-588. 
LO Lands Organization in Denmark (Federation of Danish Unions) (1980), Economic democracy - co-ownership and co-determination of employees as seen from the point of view of the Danish trade union movement, JMF/GM, Copenhagen.

Long, R. J. (1978), "The relative effects of share ownership versus control on job attitudes in an employee-owned company", Human Relations, Vol. 31, No. 9, pp. 753-763.

Long, R.J. (1978), "Employee ownerhsip and attitudes toward the union: An empirical study," Industrial Relations, Vol. 33, No. 2, pp. 237-254.

Lowitzsch, J. Hshi, I. and Woodword, R. (Eds.), (2008), The PEPPER IV Report: Benchmarking of employee participation in profits and enterprise results in the member and candidate countries of the European Union (preliminary version for presentation to the European Parliament, Strasbourg, May 21 2008), InterUniversity Centre at the Institute for Eastern European Studies, Free University of Berlin, Berlin May 2008. http://www.efesonline.org/2008/seventheuropeanmeeting/Presentations/DraftPE PPERIVReportStrasbourgEditionJensLowitzschandothers.pdf, (Accessed: 20.03.2009)

Matsunaga, S. (1995), "The effects of financial reporting costs on the use of employee stock options", The Accounting Review, Vol. 70, No.1, pp.1-26.

McHugh, P., Cutcher-Gershenfeld, J. and Polzin, M. (1999), "Employee stock ownership plans: Union influence and stakeholder interests", Economic and Industrial Democracy, Vol. 20, pp. 535-560.

Meidner, R. (1978), Employee investment funds: An approach to collective capital formation, George Allen and Unwin, London.

Melgarejo, Z., Arcelus, F.J. and Simon, K. (2007), "Measuring performance: Differences between capitalist and labour-owned enterprises", International Journal of Social Economics, Vol. 34, No. 7, pp. 485-501.

Michie, J., Oughton, C. and Bennion, Y. (2002), Employee ownership, motivation and productivity, The Work Foundation, London, November. www.efesonline.org/LIBRARY/Employees20Dircet20Report.qxd.pdf.

Monklands (2008), "The history of Coatbridge co-operative Ssciety, http://www.monklands.co.uk/CoatbridgeCo-operative/index.htm http://www.nceo.org/esops/index.html (Accessed: 03.03.2008).

Morris, D., Bakan, U. and Wood, G. (2006), "Employee financial participation: Evidence from a major UK retailer"”, Employee Relations, Vol. 28, No. 4, pp. 326-341.

NCEO, (2005a), "Employee stock options fact sheet", National Center for Employee Ownership, Oakland, CA, March, www.nceo.org/library/optionfact.html.

NCEO, (2005b), "A statistical profile of employee ownership", National Center for Employee Ownership, Oakland, CA, March, http://www.nceo.org/library/eo_stat.html (Accessed: 05.03.2008). 
NCEO, (2008a), "A Short History of the ESOP", National Centre for Employee Ownership, http://www.nceo.org/library/history.html, http://www.nceo.org/esops/index.html (Accessed: 03.03.2008)

NCEO, (2008b), "Employee Stock Ownership Plans (ESOPs)”, National Centre for Employee Ownership, http://www.nceo.org/esops/index.html (Accessed: 03.03.2008).

NCEO, (2008c), “A Statistical Profile of Employee Ownership”, National Centre for Employee Ownership, http://www.nceo.org/library/eo_stat.html http://www.nceo.org/esops/index.html (Accessed: 03.03.2008).

NCEO, (2008d), Beyond stock options: Phantom stock, restricted stock, restricted stock Units, stock appreciation rights, and other equity alternatives (6th ed.), February, http://www.nceo.org/pubs/beyondstockoptions.html

NYSE (New York Stock Exchanges). (1982), "People and productivity: A challenge to corporate America, Office of Economic Research, New York.

Obradovic, J. (1970), "Participation and work attitudes in Yugoslavia", Industrial Relations, Vol. 9, No. 2, pp.161-169.

Odoi, A. (2007), "Workers enjoy fruits of their labor", The Guardian, August 20, http://www.worldbusinesslive.com/HumanCapital/Article/733048/unsungbenefits-employee-ownership/Monday, (accessed: 20.05.2009).

Park, R., Kruse, D. and Sesil, J. (2004), "Does employee ownership enhance firm survival?" Employee Participation, Firm Performance and Survival Advances in the Economic Analysis of Participatory and Labour-Managed Firms, Vol. 8, pp. 3-33.

Pendleton, A. (1997) 'Characteristics of workplaces with financial participation: evidence from the WIRS', Industrial Relations Journal, 28, pp.103-19

Pendleton, A. (2001), Employee ownership, participation and governance: a study of ESOPs in the UK, Routledge, London.

Pendleton, A. (2005) 'Employee share ownership, employment relationships, and corporate governance', in Harley, B., Hyman, J. and Thompson, P. (eds.), Participation and Democracy at Work: Essays in Honour of Harvie Ramsay, London: Palgrave, pp. 75-93.

Pendleton, A. (2006) 'Incentives, Monitoring, and Employee Stock Ownership Plans: New Evidence and Interpretations', Industrial Relations, 45 (4), pp.753-77.

Pendleton, A., Wilson, M. and Wright, M. (1998), "The perceptions and effects of share ownership: Empirical evidence from employee buyouts", British Journal of Industrial Relations, Vol. 36, pp. 99-123.

Pérotin, V., and Robinson, A. (2003) 'Employee participation in profit and ownership: a review of the area and evidence', Luxembourg: European Parliament, Directorate General for Research: Working Paper, SOCI 109 EN.

Pfeffer, J. (1995), "Producing sustainable competitive advantage through the effective management of people", Academy of Management Executive, Vol. 9, No.1, pp. $55-69$. 
Poole, M. (1988), "Factors affecting the development of employee financial participation in contemporary Britain: Evidence from a national survey", British Journal of Industrial Relations, Vol. 26, No.1, pp. 21-36.

Poole, M. (1989), The origins of economic democracy: Profit sharing and employee shareholding schemes, Routledge, London.

Pourceau, F. (2003), Employee participation and tax obstacles in the EU, European Federation of Employee Share Ownership (EFES), Brussels.

Poutsma, E. and de Nijs, W. (2003), "Broad-based employee financial participation in the European Union", International Journal of Human Resource Management, Vol. 14, No. 6, pp. 863-92.

Poutsma, E., Kalmi, P. and Pendleton, A. (2006), "The relationship between financial participation and other forms of employee participation: New survey evidence from Europe', Economic and Industrial Democracy, Vol. 27, No. 2, pp. 637668.

Robinson, A. and Zhang, H. (2005), 'Employee share ownership: safeguarding investments in human capital, British Journal of Industrial Relations. Vol. 43, No.3, pp. $469-488$

Rosen, C. and Carberry, E. (2002), Ownership management: Building a culture of lasting innovation, National Center for Employee Ownership, Oakland, CA.

Rosen, C., Case, J. and Staubus, M. (2005a), Equity: Why employee ownership is good for business, Harvard Business School Press, Boston.

Rosen, C., Case, J. and Staubus, J. (2005b), When employees have equity attitude, Harvard Business School Working Knowledge Series.

Rosen, G. (2008), “ESOPs grow significantly in 2007”, The National Centre for Employee Ownership (NVEO), http://www.nceo.org/columns/cr247.html (accessed: 07.05.2008).

Rousseau, D.M. and Shperling, Z. (2003), "Pieces of the action: Ownership and the changing employment relationship", Academy of Management Review, Vol. 28 No.4, pp. 553-570.

Rousseau, D. M. and Shperling, Z. (2003), "Pieces of the action: Ownership and the changing employment relationship", Academy of Management Review, Vol. 28, No.4, pp. 553-570.

Rousseau, D. M. and Shperling, Z. (2004), "Ownership and the changing employment relationship: Why stylized notions of labour no longer generally apply - a reply to Zardkoohi and Paetzold", Academy of Management Review, Vol. 29, No.4, pp. 562-9.

Saunders, P. and Harris, C. (1994), Privatization and popular capitalism, Open University Press, Buckingham.

SEC (Securities and Exchange Commission) (2008), "Employee stock ownership plans (ESOPs)", http://www.sec.gov/answers/esops.htm(Accessed: 05.03.2008).

Sengupta, S. (2008), 'The impact of employee-share-ownership schemes on performance in unionized and non-unionized workplaces", Industrial Relations Journal, Vol. 39, No. 3, pp. 170-90. 
Sengupta, S., Whitfield, K. and McNabb, B. (2007), 'Employee share ownership and performance: Golden path or golden handcuffs?' The International Journal of Human Resource Management, Vol. 18, pp. 1507 - 1538.

Sesil, J. C., Kroumova, M. K., Blasi, J. R. and Kruse, D. L. (2002), "Broad-based employee stock options in U.S. 'New economy' firms", British Journal of Industrial Relations, Vol. 40, No.2, pp. 273-94.

Sesil, J. C., Kruse, D. L. and Blasi, J. R. (2003), "Sharing ownership via employee stock ownership", in Sun, L. (Ed.), Ownership and governance of enterprises: Recent innovative developments, Palgrave Macmillan, New York, pp. 96-123.

Stack, J. and Burlingham, B. (2002), A stake in the outcome: Building a culture of ownership for the long term success of your business, Currency, New York.

Tannenbaum, A. S. (1983), "Employee-owned companies", Research in Organizational Behaviour, Vol. 5, No. 2, pp. 235-268.

Uvalić, M. and D. Vaughan-Whitehead (eds.), (1997, reprinted 1999), Privatization surprises in transition economies: Employee-ownership in Central and Eastern Europe, Edward Elgar, Cheltenham.

Webb, C. (1912), Industrial cooperation: The story of a peaceful revolution, Cooperative Union, Manchester.

Zardkoohi, A. and Paetzold, R. L. (2004), "Ownership and the changing employment relationship: A comment on Rousseau and Shperling", Academy of Management Review, Vol. 29, No.4, pp. 556-562.

Zeuli, K. A. and Cropp, R. (2004), Cooperatives: Principles and practices in the 21st century, Cooperative Extension Publications, Wisconsin. 